\title{
베트남 중간년도 원조공여국 회의 결과보고
}

베트남 중간년도 원조공여국 회의 결과보고 (Informal Mid-Year Consultative Group Meeting for Vietnam)가 2005년 6월 2 3일 25개 주요 원조공여국(브라질 및 남아공은 옵저버로 참 석), $\mathrm{WB}$ 및 $\mathrm{ADB}$ 등 15 개 국제기구대표, Oxfam 등 5 개 국제 NGO 대표 및 베트남 대표 등 약 150 여 명 이 참석한 가운데 $\mathrm{WB}$ 와 베트남 정부의 공동 주관으 로 베트남 남부 메콩델타지역인 껀터(Can Tho)시에 서 비공식 회의의 형식으로 개최됨.

\section{I. 주요 의제별 토의사항}

ㅁㅡㅡ번 회의는 현재 초안 작성을 준비중인 베트남 경제사회개발 5개년계획('06 '10년간 $\mathrm{SEDP}$ ), 반 부패 활동 및 각종 분야별 개혁조치(금융, 행정개 혁, 사법시스템 개혁 등)에 대해 심도있는 토의가 이루어짐.
ㅁ 베트남 정부는 $\mathrm{SEDP}$ 의 성장목표(2010년 말까지 일인당 GDP 900불 달성)를 제시함.

- 공여국 참석자들은 $\mathrm{SEDP}$ 수립시 투명하고 합 리적인 목표수준을 설정하고 각분야의 균형을 유지하기 위해 지방정부, 민간, 기업 및 공여국 그룹과의 Consultation을 강화해야 한다는 점 을 강조

ㅁ 반부패 및 분야별 개혁조치와 관련 베트남 정부는 법치주의(Rule of Law) 원칙의 확산을 비롯하여 제반 개혁조치를 차질 없이 추진중이며, 이 같은 노력을 강화할 것이라고 소개함.

- 개혁의 추진을 위해 선진국들의 경험 전수, 공무 원 등 인력 훈련 등 Capacity Building을 위한 공여국들의 지원을 요청함.

- 공여국들은 베트남 정부의 추진의지를 높이 평 가하면서도 개혁이 지연되는 문제(특히 금융부 문)를 지적하고 향후 법치주의 강화, 개혁의 투 명성 및 일관성 확보에 노력해 줄 것을 요청함. 
모류독감 및 AIDS 예방과 관련, 베트남 정부는 신 속예방 및 탐지 시스템 구축을 위한 시설 및 인력 의 부족을 지적하고 공여국들의 지원을 요청함.

-공여국들은 조류독감 및 $\mathrm{AIDS}$ 의 심각성을 지적 하고 가능한 범위의 지원을 검토키로 함.

WTO 가입과 관련, 베트남 정부는 연말가입을 위 해 각국정부의 지원을 요망함.

-NGO 단체들은 선진국들이 베트남의 WTO 가 입 요구조건을 너무 많이 요구한다고 비난하고, WTO 가입시 부정적 영향을 받을 수 있는 소외 계층에 대한 사회안전망 구축, $\mathrm{WTO}$ 가입조건 의 합리적 완화 등을 요구함.

-우리 대표단은 6.1 서울에서 한-베 양자협상이 최종타결된 것을 발표하고 한-베 협상타결이 여타국과의 협상추진에 모멘텀으로 작용하게 될 것을 기대함.

※ Vu Khoan 부총리는 수석대표 오찬을 주최한 자리 에서 우리 측 수석대표에게 사의를 표하였음.

ㅁ 베트남 정부와 공여국 그룹은 $\mathrm{OECD} \mathrm{DAC}$ (원조 지원 위원회) 채택된 원조조화계획을 베트남에 적용하기 위한 Hanoi Core Statement(HSC)를 발표함.

- 덴마크 등 대부분 참가국들은 금번 회의에서는 $\mathrm{HSC}$ 에 대한 적극적 지지의사를 표명하고 이를 승인할 것을 적극 주장

-미국, 프랑스 등은 본부 지침이 없다는 이유로 $\mathrm{HSC}$ 승인에는 부정적 입장을 보였으나, 일단 $\mathrm{HSC}$ 의 평가기준은 원안대로 승인하되, 2010년 목표부분은 추후 협의하는 선에서 합의되었음.

\section{II. 관찰 및 평가}

믐번 회의에서 공여국들은 베트남 $\mathrm{SEDP}$ 에 대해 높은 관심을 보였으며 베트남 측도 공여국들의 조 언을 적극 수용하는 입장을 보임.

-다만, CG 회의 특성상 경제개발 목표 및 전략, 발전 모델, 투자우선 순위 선정 등 경제적 - 전략 적 고려보다는 사회안전망 구축, 행정 개혁, 보 건 · 교육, 지역간 균형개발 및 빈곤 감축 등 사 회적 이슈에 다소 편향된 것으로 관찰됨.

※일본이 산업경쟁력 강화방안을 지적하였으나 다른 참가국의 관심을 끌지 못함.

-특히, 공여국들은 SEDP 수립시 지방정부, 민간 부문, 공여국의 참여와 협의를 강력히 요청하는 등 민주적이고 참여적인 $\mathrm{SEDP}$ 형성과정을 강 조함.

WTO 가입, 반부패 및 각종 개혁조치와 조류독감, $\mathrm{AIDS}$ 등 질병통제 분야에서도 심도있는 토의가 진행되었으나 궁극적으로는 베트남의 제도적 측 면과 인적자원 측면, 기초 인프라 등 세 가지 분야 에서 Capacity Building이 시급히 필요하다는 데 의견이 집약됨.

-베트남 정부는 Capacity Building에 필요한 공여 국의 원조를 요청하고 공여국들은 이에 대한 적극적 지원 의사를 표명함.

ㅁ 금번 회의에 제출되고 공여국들의 승인을 받은 원 조 효율성에 관한 Hanoi Core Statement는 베트 남뿐 아니라 원조 공여국들의 지원방식과 지원사 업에도 영향을 미칠 수 있을 것으로 판단됨. 
-특히 HCS는 예측 가능성(사전 스케쥴에 입각한 지원) 제고과, 환경 및 사회적 영향 평가 적용, 예산회계 제도 및 감사원칙 적용 등을 규정하고 있어 동 $\mathrm{HCS}$ 가 우리나라 유무상 원조도 방식에 미치는 영향이 클 것으로 판단되는 바, 이에 대 한 본부와 관계부처간의 심도 있는 검토를 진행 해 줄 것을 건의함.

한편, CG 회의는 베트남 경제사회개발 계획과 각 종 개혁 등 대상 분야가 넓어지고 폭도 깊어지는 등 그 중요성이 커지고 있으며 이에 따라 각 $\mathrm{NGO}$ 의 참여도 지속적으로 확대되고 있음.
-특히 CG 회의는 연 2회 정기회의 외에도 각종 실무 그룹회의(WG)가 수시로 개최되는 바, 한베간 원조 사업 협의뿐 아니라 베트남 각종 정책 의 개선을 유도할 수 있는 유용한 기회가 될 것 으로 판단되는 바, 주베트남 대사는 향후 실무회 의 참가 확대 등 적극적인 $\mathrm{CG}$ 회의 참가를 추진 할 계획임.

[자료:주베트남 KOICA사무소] 